\title{
Genotype $\times$ Environment Interactions and Stability Analysis for Grain Iron and Zinc Concentrations in Rice (Oryza sativa L.) Genotypes
}

\author{
Sriram Ajmera $^{1 *}$, S. Sudheer Kumar ${ }^{1}$ and V. Ravindrababu ${ }^{2}$ \\ ${ }^{1}$ Department of Genetics and Plant Breeding, College of Agriculture, PJTSAU, Rajendranagar, \\ Hyderabad, Telangana, India \\ ${ }^{2}$ Indian Institute of Rice Research, Rajendranagar, Hyderabad, Telangana, India \\ *Corresponding author
}

\section{A B S T R A C T}

Micronutrient enrichment in the major staple food crops is an important breeding

Keywords

Environment, Grain iron, Rice, Stability,

Variability, Zinc.

Article Info

Accepted:

21 June 2017

Available Online:

10 July 2017 goal in view of the extensive problem of 'hidden hunger' caused by micronutrient malnutrition. Grain iron $(\mathrm{Fe})$ and zinc $(\mathrm{Zn})$ concentrations were evaluated in a set of 37diverse rice genotypes during rainy (kharif) season of 2013. Based on the performance of the entries across the locations, highly promising for kernel $\mathrm{Fe}$ concentration among genotypes studied, the genotypes RPHP 106, RPHP 114, RPHP 134 and RPHP 135 were considered stable as they recorded high mean $(\mu)$ with regression coefficient $\left(b_{i}\right)$ near 'unity' and non-significant deviation from regression $\left(S^{2} d_{i}\right)$. Similarly, for kernel $\mathrm{Zn}$ concentration among the genotypes studied, the genotypes RPHP 81, RPHP 84, RPHP 103 and RPHP 157 were considered stable as they recorded high mean $(\mu)$ with unit regression coefficient $\left(b_{i}\right)$ and non-significant deviation from regression $\left(S^{2} d_{i}\right)$ and considered as stable based on Eberhart and Russell (1966) stability criteria.

\section{Introduction}

Nearly one billion people worldwide are undernourished due to insufficient food, and more than double this population, mostly the resource-poor in the developing world, suffer from 'hidden hunger', a term more often used to describe malnutrition due to micronutrient deficiencies in staple food diet (Bouis and Welch 2010, FAO 2010). Two-thirds of all deaths among the children below five years were reported due to micronutrient deficiencies (Welch and Graham, 2004).The micronutrient deficiencies are particularly concentrated in the semi-arid tropics, especially in South and South East Asia and
Sub-Saharan Africa (Reddy et al., 2005). In India, 230 million people were reported to be undernourished, accounting for more than $27 \%$ of the world's undernourished population (Lodha et al., 2005).

Among various micronutrient deficiencies, $\mathrm{Fe}$ deficiency is the most common nutritional disorder, affecting 4-5 billion of people worldwide, with more than two billion people in the developing countries (Ghandilyan et al., 2006). In India, nearly $70 \%$ of the children (under five years) suffer from anemia (Lodha et al., 2005). Fe-related deficiencies 
also affect development, growth, reproductive performance and work productivity (Lynch, 2003; Bouis, 2002). Zinc deficiency leads to anorexia, depression and psychosis, impaired growth and development, altered reproductive biology, gastro-intestinal problems and impaired immunity (Solomons, 2003). Cichy et al., (2005) reported that $49 \%$ of the world's population is affected by low zinc intake. Medical supplements and fortification of food products have been attempted in several countries for decades to ameliorate problems of 'hidden hunger' (Underwood, 2000), but these measures have their inherent limitations in terms of their reach, besides lack of purchasing power of the poor (Pfeiffer and McClafferty, 2007).

Rice is a staple food for millions of people and having great importance in food and nutritional security. Rice (Oryza sativa L.) is the major food crop in India occupying nearly 44.00 million hectares with an annual production of 118.16 million tonnes and productivity of $2372 \mathrm{~kg} \mathrm{ha}^{-1}$. While, in Telangana it is grown in an area of 17.89 lakh hectares with production of 51.47 lakh tonnes and the productivity is $2942 \mathrm{~kg} \mathrm{ha}^{-1}$ (Ministry of Agriculture, GOI, 2011-12).

Biofortification is a genetic approach which aims at biological and genetic enrichment of food stuffs with vital nutrients (vitamins, minerals and proteins). Ideally, once rice is biofortified with vital nutrients, the farmer can grow indefinitely without any additional input to produce nutrient packed rice grains in a sustainable way. This is also the only feasible way of reaching the malnourished population in India.

Fortification has proven to be an effective long-term nutrition intervention strategy, and rice has emerged as a staple food with much potential as a food fortification vehicle. Rice provides $50 \%$ of calories for more than half of the world population. However, a lack of micronutrients in white rice has become a problem for countries with high consumption rates of rice. Low intakes of iron, vitamin A, and iodine are a major concern, while low zinc intake is also a problem. An experimental product, extruded rice kernels manufactured from rice flour fortified with vitamins and minerals, has been proposed as an effective vehicle for delivering a variety of micronutrients to low income populations.

In this context breeders are now focusing on breeding for nutritional enhancement to overcome the problem of malnutrition. The range of iron and zinc concentration in brown rice is $6.3-24.4 \mu \mathrm{g} \mathrm{g}^{-1}$ and $13.5-28.4 \mu \mathrm{g} \mathrm{g}^{-1}$ respectively. There are four fold differences in iron and zinc concentrations, suggesting some genetic potential to increase the concentration of these micronutrients in rice grains (Gregorio, 2002).

Development of 'golden rice' is one of the classical examples of plant biofortification to fight the menace of vitamin A deficiency (Ye et al., 2000). Development of micronutrientrich cultivars would produce more yields in a micronutrient-deficient soil than the micronutrient inefficient variety. Assessment of the stability of genotypes with respect to target traits is important for effective utilization of such genotypes in breeding strategies.

In static concept, the term stability was used to characterize a genotype which always shows a constant performance whatever the environmental conditions might be. According to the dynamic concept, a stable genotype is one which gives predictable performance over environments without any deviation (Becker and Leon, 1988). Consistent performance in respect to productivity over a wide range of environments is one of the most desirable 
properties of a genotype to be released as a variety or hybrid. Genotype and Environment interactions are important in developing stable genotypes which interact less with the environment. Rice breeding aimed to develop high yielding stable genotypes.

Yield is a polygenically controlled complex character and highly influenced by genotype and environment interactions. Hence, developing a stable variety with high yield potential and good grain quality is of paramount importance to the plant breeder through selection of varieties that interact less with environment in which they are grown. Evaluation of genotype $\mathrm{x}$ environment interaction gives an idea of the buffering capacity of the rice genotypes under different environments, thereby enabling plant breeder to recommend appropriate varieties to suit Telangana, particularly for kharif season. With this background the present investigation was under taken to study the $G$ $\mathrm{X} \mathrm{E}$ interaction of newly developed rice lines with high Iron and Zinc.

\section{Materials and Methods}

The experiment was laid out in a Randomized Block Design (RBD) with three replications. The nursery was sown in raised beds and healthy nursery was raised at all the locations following uniform package of practices. Thirty days old seedlings were transplanted following a spacing of $20 \times 15 \mathrm{~cm}$ with a row length of $4.5 \mathrm{~m}$ for each entry.

A set of 35 rice entries, along with two checks were analyzed for grain $\mathrm{Fe}$ and $\mathrm{Zn}$ concentrations at the three loactions: Location I: Agricultural Research Station, Kampasagar, Nalgonda district. Location II: Regional Agricultural Research Station, Jagtial, Karimnagar district. Location III: DRR farm, ICRISAT, Patancheru, Medak. During rainy (kharif) season of 2013, the genotypes were planted in a randomized block design (RCBD) with three replications following a spacing of $20 \times 15 \mathrm{~cm}$ with a row length of $4.5 \mathrm{~m}$ for each entry. The soil status of the experimental block and the three locations recorded during the experimental season at three stages of crop growth (2013) are presented in (Table 2). After grain maturation panicle were hand harvested and was dried under the clean shade to lower post-harvest grain moisture content to $14 \%$,as per the protocol suggested by Harvest Plus.

Iron and zinc content of grain samples was estimated by Atomic Absorption spectrophotometer. One gram of seed was taken and powdered it in the grinder (nonmetallic grinder). Powdered seed sample was digested in tri-acid $\left(\mathrm{HNO}_{3}+\mathrm{HCl}_{4}+\mathrm{H}_{2} \mathrm{SO}_{4}\right)$ mixture (10:4:1) in micro-oven digester. The digested sample was cooled for 30 minutes and the volume was made up to $50 \mathrm{ml}$ with double distilled water. Then a known quantity of aliquot was used for subsequent analysis. A suitable blank was run simultaneously to account for the contamination from the reagents. Zinc and Iron content was estimated in the aliquot of seed extract by using Atomic Absorption Spectrophotometer (AAS) at $213.86 \mathrm{~nm}$ for Zinc and $248.33 \mathrm{~nm}$ for iron.

The soil Fe and $\mathrm{Zn}$ were analyzed following DTPA extractable method at DRR Lab and expressed as $\mathrm{mg} \mathrm{kg}^{-1}$. Ten grams of air-dried soil was placed in a 125 $\mathrm{ml}$ conical flask and $20 \mathrm{ml}$ of DTPA extracting solution was added. Each flask was covered with screw cap and placed on a horizontal shaker with a stroke of $8.0 \mathrm{~cm}$ and with a speed of 120 cycle's m. After 2 hours shaking, the suspension was filtered by gravity through Whatman No. 42 filter paper. The filtrates were analyzed for $\mathrm{Fe}$ and $\mathrm{Zn}$ using atomic absorption spectrophotometer (AAS) (Sahrawat et al., 2002) with appropriate standards included 
in the analysis (Table 1). The analysis of variance for each location was conducted the mean genotypic values for each location was taken for analyzing the data over location. The characters which recorded significant $G$ $\mathrm{X} \mathrm{E}$ were used for stability analysis of Eberhart and Russell model (1966). A genotype with unit regression coefficient $\left(b_{i}=1\right)$ and deviation not significantly different from zero $\left(S^{2} d_{i}=0\right)$ was taken to be a stable genotype with unit response.

\section{Results and Discussion}

The present investigation was carried out to evaluate thirty seven genotypes in three locations viz., Directorate of Rice Research farm at ICRISAT, Medak for Central Telangana Zone, Regional Agricultural Research Station, Jagtial, Karimnagar for Northern Telangana Zone and Agricultural Research Station, Kampasagar, Nalgonda for Southern Telangana Zone of Telangana state for the stability of the genotypes for grain Iron and Zinc concentrations. The results obtained are presented below under the following headings.

\section{Analysis of variance}

Thirty seven rice genotypes including two checks (1702, 1708) obtained from Directorate of Rice Research, Hyderabad, were subjected to pooled analysis of variance for Grain Iron content and Grain Zinc content. The analysis of variance (Table 2) showed significant difference among the genotypes for all the characters studied in all the environments. It indicates that there is significant variation among genotypes, which can be further studied for their interaction with different environments to identify for their suitability for cultivation.

The pooled analysis of variance (Table 3) indicated significant variation among the Environments, Genotypes and Genotype $\mathrm{x}$
Environment interaction for all the characters studied. The significance of Genotype and Environment interaction suggests that genotypes behaved differently in different environment. Similar kind of results earlier reported by Oikeh et al., (2004), Velu et al., (2012), Suwarto and Nasrullah (2011) and Prasanna et al., (2011).

\section{Mean performance of genotypes}

The three locations viz., Directorate of Rice Research farm at ICRISAT, Medak for Central Telangana Zone, Regional Agricultural Research Station, Jagtial, Karimnagar for Northern Telangana Zone and Agricultural Research Station, Kampasagar, Nalgonda for Southern Telangana Zone were utilized to investigate the mean values for Grain Fe content and Grain Zn content.

\section{Grain Iron content (mg/kg)}

Analysis of soil samples of three locations concluded that the ICRISAT soils have high Iron content and Kampasagar have low. At Kampasagar Iron content in soils at transplanting, $50 \%$ flowering and at harvesting was $7.40 \mathrm{mg} / \mathrm{kg}, 6.80 \mathrm{mg} / \mathrm{kg}$ and $6.45 \mathrm{mg} / \mathrm{kg}$ respectively. The Iron content in soils of Jagtial, at transplanting $11.00 \mathrm{mg} / \mathrm{kg}$, at $50 \%$ flowering $10.55 \mathrm{mg} / \mathrm{kg}$ and at harvesting $10.10 \mathrm{mg} / \mathrm{kg}$ and at ICRISAT Iron content at transplanting, 50\% flowering and at harvesting is $28.10 \mathrm{mg} / \mathrm{kg}, 27.56 \mathrm{mg} / \mathrm{kg}$ and $27.12 \mathrm{mg} / \mathrm{kg}$ respectively.

At Kampasagar, grain iron content ranged from $8.85 \mathrm{mg} / \mathrm{kg}$ (RPHP 16) to $19.78 \mathrm{mg} / \mathrm{kg}$ (RPHP 108) with a mean of $11.31 \mathrm{mg} / \mathrm{kg}$ (Table 5). The genotype RPHP 108 recorded the highest grain Iron content. The genotypes RPHP 92, RPHP106, RPHP 107, RPHP 108, RPHP 114, RPHP 130, RPHP 134, RPHP 135 and RPHP 166 were significantly superior to the best check $1702(10.45 \mathrm{mg} / \mathrm{kg})$. 
At Jagtial, the mean values of grain Iron content (Table 4) ranged from $7.53 \mathrm{mg} / \mathrm{kg}$ (RPHP 90) to $14.70 \mathrm{mg} / \mathrm{kg}$ (RPHP 114) with mean $11.00 \mathrm{mg} / \mathrm{kg}$. The genotypes RPHP 51, RPHP 134, RPHP 130, RPHP 135 and RPHP 157 were on par with the RPHP 114 which recorded the highest grain Iron content. Among the genotypes studied, the genotypes RPHP 51, RPHP 114, RPHP 134, RPHP 135 and RPHP 157 were significantly superior to the best check $1702(11.73 \mathrm{mg} / \mathrm{kg})$.

The mean values of genotypes for grain Iron content (Table 4) at ICRISAT ranged from $8.95 \mathrm{mg} / \mathrm{kg}$ (RPHP 90) to $16.57 \mathrm{mg} / \mathrm{kg}$ (RPHP 48) with general mean $10.93 \mathrm{mg} / \mathrm{kg}$. The genotype RPHP 48 recorded the highest grain Iron content and significantly superior to other genotypes. The genotypes RPHP 16, RPHP 48, RPHP 80, RPHP 106, RPHP 108, RPHP 114, RPHP 134 and RPHP 135 were significantly superior to the best check 1702 $(11.30 \mathrm{mg} / \mathrm{kg})$ for this trait.

In pooled analysis, the mean of grain Iron content (Table 4) ranged from $9.11 \mathrm{mg} / \mathrm{kg}$ (RPHP 45) to $14.84 \mathrm{mg} / \mathrm{kg}$ (RPHP 134) with overall mean of $11.05 \mathrm{mg} / \mathrm{kg}$. The genotypes RPHP 48, RPHP 106, RPHP 108, RPHP 114, RPHP 130 and RPHP 135 were on par with the genotype RPHP 134 which records the highest grain Iron content. The genotypes RPHP 48 and RPHP 51, RPHP 114, RPHP 134, RPHP 130, RPHP 135 and RPHP 135 were significantly superior to the best check $1708(10.60 \mathrm{mg} / \mathrm{kg})$ for grain Iron content. Figure 1 shows the top five genotypes for grain Iron content at Kampasagar, Jagtial and ICRISAT.

\section{Grain zinc content (mg/kg)}

Analysis of soil samples of three locations indicated that the ICRISAT soils have low Zinc content and Jagtial soils have high Zinc content. The zinc content in soils of Kampasagar, at transplanting was $0.76 \mathrm{mg} / \mathrm{kg}$, at $50 \%$ flowering $0.91 \mathrm{mg} / \mathrm{kg}$ and at harvesting it was $0.86 \mathrm{mg} / \mathrm{kg}$. At Jagtial zinc content at transplanting, 50\% flowering and at harvesting is $1.09 \mathrm{mg} / \mathrm{kg}, 1.25 \mathrm{mg} / \mathrm{kg}$ and $1.10 \mathrm{mg} / \mathrm{kg}$ respectively. At ICRISAT zinc content at transplanting, 50\% flowering and at harvesting is $0.41 \mathrm{mg} / \mathrm{kg}, 0.54 \mathrm{mg} / \mathrm{kg}$ and $0.47 \mathrm{mg} / \mathrm{kg}$ respectively.

At Kampasagar, the mean of grain Zinc content ranged from $12.80 \mathrm{mg} / \mathrm{kg}$ (RPHP16) to $31.20 \mathrm{mg} / \mathrm{kg}$ (RPHP 92) with a mean of $13.05 \mathrm{mg} / \mathrm{kg}$ (Table 4). The genotype RPHP 92 recorded highest grain Zinc content and was statistically superior to other genotypes. The genotype RPHP 92 was significantly superior to the best check 1702 (20.35 $\mathrm{mg} / \mathrm{kg}$ ).

At Jagtial, grain Zinc content (Table 4) ranged from $9.50 \mathrm{mg} / \mathrm{kg}$ (RPHP 10) to 23.30 $\mathrm{mg} / \mathrm{kg}$ (RPHP 91) with mean $16.13 \mathrm{mg} / \mathrm{kg}$. The genotypes RPHP 56, RPHP 92, RPHP 130, RPHP 158 and 1702 were on par with the genotype RPHP 91 which recorded the highest grain Zinc content. The genotype RPHP 91 was significantly superior to the best check $1702(21.60 \mathrm{mg} / \mathrm{kg})$.

For the character grain zinc content (Table 4) the observed range at ICRISAT was from $19.90 \mathrm{mg} / \mathrm{kg}$ (RPHP 56) to $39.93 \mathrm{mg} / \mathrm{kg}$ (RPHP 91), with mean $28.25 \mathrm{mg} / \mathrm{kg}$. The genotypes RPHP 84, RPHP 92 were on par with RPHP 91 which recorded the highest grain Zinc content. The genotypes RPHP 84, RPHP 92 and RPHP 91 were significantly superior to the best check 1708 (30.57).

In pooled analysis, the mean performance of grain zinc content (Table 4) ranged from $14.51 \mathrm{mg} / \mathrm{kg}$ (RPHP 90) to $29.83 \mathrm{mg} / \mathrm{kg}$ (RPHP 92) with a mean of $21.10 \mathrm{mg} / \mathrm{kg}$. The genotypes RPHP 84 and RPHP 91 were on par with RPHP 92 which recorded the highest grain Zinc content. The genotypes RPHP 92 and RPHP 91 were significantly superior to 
the best check $1702(23.32 \mathrm{mg} / \mathrm{kg})$. Fig: 2 shows the top five genotypes for grain Zinc content at Kampasagar, Jagtial and ICRISAT.

\section{Stability analysis}

Rice is the staple crop and important cereal crop of India, being a thermo and photosensitive in nature, due to its buffering capacity it is being cultivated round the year in different agro-climatic zones of the country. However, the genotypes and breeding material likely to interact differently with different environments.

The cultivated varieties and hybrids though having high yield potential, they are erratic in their performance even under less varied conditions of cultivation. Lack of genotypes suitable to specific locations accounts for the decline in the area and productivity in rice, apart from the biotic and abiotic stresses. This warrants the attention of the plant breeders to evolve superior genotypes that would sustain well in the strainful situation. Therefore, assessment of its adaptability is of important concern. Productivity of a population is the function of its adaptation, whereas stability is the statistical measure of genotype $x$ environment interaction.

\section{Pooled analysis of variance}

The results of pooled analysis of variance for stability as devised by Eberhart and Russell (1966) are presented in table 4. The thirty seven genotypes showed significant differences for all the characters, when tested against pooled error and pooled deviation. It reveals that the selected genotypes are having significant variation for all characters. When tested against showing uniform performance in different environments. Significant differences among genotypes for these traits were earlier reported by Lal and Pal Singh (2012), Mosavi et al., (2013), Somana et al., (2013) and Tariku et al., (2013).

Environments showed highly significant differences for both the characters under study, when tested against pooled error while, grain Iron content showed non-significant variances, when tested against pooled deviation. It reveals that wide difference between environments. Significant differences due to environments for these traits were earlier reported by Rasyad et al., (2012), Mosavi et al., (2013), Somana et al., (2013) and Tariku et al., (2013).

Whereas, Genotype x Environment interaction components showed highly significant differences for all the characters, when tested against pooled error. The Genotype X Environment interaction for grain zinc content showed significantly differences, when tested against pooled deviation. It Indicates wide differential behavior of genotypes in changing environments, Mosavi et al., (2013), Somana et al., (2013) and Tariku et al., (2013) also reported the differential response of varieties due to $\mathrm{G} \times \mathrm{E}$ interaction.

Table.1 Soil sample analysis at three locations

\begin{tabular}{|c|c|c|c|c|c|c|}
\hline \multirow{2}{*}{ location } & \multicolumn{3}{|c|}{ Fe(mg/kg) } & \multicolumn{3}{c|}{ Zn(mg/kg) } \\
\cline { 2 - 7 } & $\begin{array}{c}\text { At } \\
\text { transplanting }\end{array}$ & $\mathbf{5 0 \% \text { flowering }}$ & $\begin{array}{c}\text { At } \\
\text { maturity }\end{array}$ & $\begin{array}{c}\text { At } \\
\text { transplanting }\end{array}$ & 50\%flowering & $\begin{array}{c}\text { At } \\
\text { maturity }\end{array}$ \\
\hline Kampasagar & 7.40 & 6.80 & 6.45 & 0.76 & 0.91 & 0.86 \\
\hline Jagtial & 11.00 & 10.55 & 10.10 & 1.09 & 1.25 & 1.10 \\
\hline ICRISAT & 28.1 & 27.56 & 27.12 & 0.41 & 0.54 & 0.47 \\
\hline
\end{tabular}


Table.2 Location wise analysis of variance for Grain iron and zinc concentrations in rice (Oryza sativa L.) Genotypes

\begin{tabular}{|c|c|c|c|c|c|c|c|c|c|c|c|c|}
\hline \multirow{3}{*}{ Character } & \multicolumn{4}{|c|}{ Kampasagar } & \multicolumn{4}{|c|}{ Jagtial } & \multicolumn{4}{|c|}{ ICRISAT } \\
\hline & & lean sum of $s$ & are & & & Mean sum of & uare & & & Mean & n of squ & \\
\hline & Replication & Treatments & Error & Total & Replication & Treatments & Error & Total & Replication & Treatments & Error & Total \\
\hline $\begin{array}{c}\text { Grain Iron } \\
\text { content }\end{array}$ & $19.8^{*}$ & 33.70 $* *$ & 3.46 & 13.68 & 1.85 & $10.46^{* *}$ & 0.97 & 4.096 & 0.162 & $8.84 * *$ & 0.21 & 3.03 \\
\hline $\begin{array}{c}\text { Grain Zinc } \\
\text { content }\end{array}$ & 1.03 & $199.38 * *$ & 2.43 & 66.86 & $51.59 * *$ & $37.17 * *$ & 4.51 & 16.06 & $42.62 *$ & $65.90 * *$ & 6.33 & 26.49 \\
\hline
\end{tabular}

Table.3 Pooled analysis of variance for Grain iron and zinc concentrations in rice (Oryza sativa L.) Genotypes

\begin{tabular}{|c|c|c|c|c|c|}
\hline \multirow{2}{*}{ Character } & $\begin{array}{c}\text { Replications within } \\
\text { environments }\end{array}$ & Environments & Genotypes & Genotypes*Environment & $\begin{array}{c}\text { Pooled } \\
\text { error }\end{array}$ \\
\cline { 3 - 6 } & $\mathbf{6}$ & 2 & 36 & $\mathbf{7 2}$ & 216 \\
\hline $\begin{array}{c}\text { Grain Iron } \\
\text { content }\end{array}$ & $\mathbf{0 . 4 4}$ & $\mathbf{4 . 4 8 * *}$ & $\mathbf{2 1 . 5 2 * *}$ & $\mathbf{7 . 4 8} * *$ & 0.65 \\
\hline $\begin{array}{c}\text { Grain Zinc } \\
\text { content }\end{array}$ & $\mathbf{1 2 . 6 7}$ & $\mathbf{4 4 6 9 . 0 8 * *}$ & $\mathbf{8 2 . 3 1 * *}$ & $\mathbf{2 7 . 2 7} * *$ & 4.77 \\
\hline
\end{tabular}

*Significant at 5 per cent level of significance, ** Significant at 1 per cent level of significance

Table.4 Analysis of variance for Grain iron and zinc content stability in Rice (Oryza sativa L.) Genotypes

\begin{tabular}{|c|c|c|c|}
\hline \multirow[t]{2}{*}{ Source } & \multirow[t]{2}{*}{ df } & \multicolumn{2}{|c|}{ Mean sum of squares } \\
\hline & & Grain Iron content & Grain Zinc content \\
\hline Genotypes & 36 & 7.17**@@@ & 27.43***@@ \\
\hline Environments & 2 & $1.49 * *$ & 1489.63**@@@ \\
\hline Genotype X Environment & 72 & $2.49 * *$ & 9.09**@ \\
\hline $\begin{array}{c}\text { Environment + (Genotype } \mathrm{X} \\
\text { Environment) }\end{array}$ & 74 & $2.46 * *$ & 49.10**@@@ \\
\hline Environment (linear) & 1 & $2.99 * *$ & 2979.38**@@@ \\
\hline $\begin{array}{c}\text { Genotype X Environment } \\
\text { (linear) }\end{array}$ & 36 & $2.27 * *$ & $11.57 * *$ \\
\hline Pooled deviation & 37 & $2.64 * *$ & $6.43 * *$ \\
\hline Pooled error & 216 & 0.21 & 1.59 \\
\hline
\end{tabular}

*, ** Significance at 5 percent and 1 percent level of significance respectively when tested against pooled error

@, @ @ Significance at 5 percent and 1 percent level of significance respectively when tested against pooled deviation 
Table.5 Mean performance of Rice genotypes for grain Iron content and grain Zinc content at KAMPASAGAR, JAGTIAL, ICRISAT and pooled analysis

\begin{tabular}{|c|c|c|c|c|c|c|c|c|c|}
\hline \multirow[b]{2}{*}{$\begin{array}{c}\text { S. } \\
\text { NO }\end{array}$} & \multirow[b]{2}{*}{ Genotypes } & \multicolumn{4}{|c|}{ Grain Iron content } & \multicolumn{4}{|c|}{ Grain Zinc content } \\
\hline & & Kampasagar & Jagtial & ICRISAT & $\begin{array}{c}\text { Pooled } \\
\text { mean }\end{array}$ & Kampasagar & Jagtial & ICRISAT & $\begin{array}{c}\text { Pooled } \\
\text { mean }\end{array}$ \\
\hline 1 & RPHP-7 & 10.15 & 8.80 & 8.97 & 9.31 & 15.80 & 9.93 & 21.53 & 15.76 \\
\hline 2 & RPHP-10 & 10.15 & 9.43 & 10.05 & 9.88 & 19.25 & 9.50 & 25.00 & 17.92 \\
\hline 3 & RPHP-16 & 8.85 & 10.40 & 12.07 & 10.44 & 12.80 & 13.90 & 26.57 & 17.76 \\
\hline 4 & RPHP-21 & 9.75 & 10.80 & 10.36 & 10.30 & 16.05 & 11.90 & 26.63 & 18.19 \\
\hline 5 & RPHP-37 & 10.50 & 9.40 & 11.75 & 10.55 & 19.15 & 16.43 & 30.90 & 22.16 \\
\hline 6 & RPHP-45 & 9.35 & 8.70 & 9.27 & 9.11 & 19.15 & 18.30 & 25.43 & 20.96 \\
\hline 7 & RPHP-48 & 15.30 & 8.27 & 16.57 & 13.38 & 21.65 & 13.20 & 29.63 & 21.49 \\
\hline 8 & RPHP51 & 9.45 & 14.37 & 9.10 & 10.97 & 16.50 & 13.03 & 23.20 & 17.58 \\
\hline 9 & RPHP-52 & 10.00 & 10.10 & 9.33 & 9.81 & 16.55 & 15.80 & 23.80 & 18.72 \\
\hline 10 & RPHP-56 & 11.40 & 12.40 & 9.05 & 10.95 & 19.40 & 22.07 & 19.90 & 20.46 \\
\hline 11 & RPHP59 & 10.85 & 10.07 & 9.60 & 10.17 & 20.55 & 13.60 & 25.77 & 19.97 \\
\hline 12 & RPHP 80 & 10.90 & 11.83 & 12.50 & 11.74 & 20.60 & 14.37 & 27.13 & 20.70 \\
\hline 13 & RPHP 81 & 11.10 & 8.67 & 11.01 & 10.26 & 20.80 & 14.10 & 34.30 & 23.07 \\
\hline 14 & RPHP84 & 10.50 & 9.43 & 9.07 & 9.67 & 21.85 & 15.33 & 38.57 & 25.25 \\
\hline 15 & RPHP87 & 9.80 & 12.33 & 11.40 & 11.18 & 19.05 & 17.80 & 26.57 & 21.14 \\
\hline 16 & RPHP90 & 8.90 & 7.53 & 8.95 & 8.46 & 13.60 & 9.93 & 20.00 & 14.51 \\
\hline 17 & RPHP91 & 11.00 & 11.23 & 11.45 & 11.23 & 21.40 & 23.30 & 39.93 & 28.21 \\
\hline 18 & RPHP92 & 13.40 & 11.47 & 11.95 & 12.27 & 31.20 & 21.93 & 36.37 & 29.83 \\
\hline 19 & RPHP 103 & 11.05 & 8.87 & 11.70 & 10.54 & 22.15 & 18.17 & 30.93 & 23.75 \\
\hline 20 & RPHP 104 & 10.85 & 12.67 & 10.60 & 11.37 & 21.70 & 15.43 & 23.23 & 20.12 \\
\hline 21 & RPHP 105 & 9.00 & 10.37 & 10.45 & 9.94 & 22.10 & 17.07 & 25.27 & 21.48 \\
\hline 22 & RPHP 106 & 12.35 & 12.60 & 13.55 & 12.83 & 19.35 & 17.73 & 25.13 & 20.74 \\
\hline 23 & RPHP 107 & 12.05 & 9.23 & 11.10 & 10.79 & 19.50 & 15.60 & 31.87 & 22.32 \\
\hline 24 & RPHP 108 & 19.78 & 12.30 & 12.40 & 14.83 & 21.65 & 16.77 & 29.57 & 22.66 \\
\hline 25 & RPHP 114 & 15.35 & 14.70 & 13.25 & 14.43 & 21.20 & 17.50 & 26.63 & 21.78 \\
\hline 26 & RPHP 129 & 9.60 & 11.90 & 9.25 & 10.25 & 16.75 & 15.03 & 26.23 & 19.34 \\
\hline 27 & RPHP 130 & 13.40 & 13.23 & 11.60 & 12.74 & 13.95 & 22.70 & 30.00 & 22.22 \\
\hline 28 & RPHP 134 & 17.25 & 13.57 & 13.70 & 14.84 & 17.15 & 15.90 & 31.27 & 21.44 \\
\hline 29 & RPHP 135 & 11.95 & 13.93 & 13.40 & 13.09 & 14.55 & 13.47 & 26.70 & 18.24 \\
\hline 30 & RPHP 138 & 10.50 & 9.23 & 9.30 & 9.68 & 19.15 & 17.13 & 30.57 & 22.28 \\
\hline 31 & RPHP 157 & 11.70 & 13.33 & 10.50 & 11.84 & 19.95 & 18.30 & 33.77 & 24.01 \\
\hline 32 & RPHP 158 & 10.45 & 11.73 & 9.45 & 10.54 & 20.35 & 21.60 & 28.00 & 23.32 \\
\hline 33 & RPHP 163 & 9.10 & 11.40 & 11.30 & 10.60 & 16.65 & 15.87 & 30.57 & 21.03 \\
\hline 34 & RPHP 165 & 10.10 & 8.73 & 10.45 & 9.76 & 16.10 & 13.57 & 32.40 & 20.69 \\
\hline 35 & RPHP 166 & 13.30 & 11.07 & 9.55 & 11.31 & 15.60 & 13.37 & 23.43 & 17.47 \\
\hline & 1702 & 10.45 & 11.73 & 9.45 & 10.54 & 20.35 & 21.60 & 28.00 & 23.32 \\
\hline & 1708 & 9.10 & 11.40 & 11.30 & 10.60 & 16.65 & 15.87 & 30.57 & 21.03 \\
\hline & G.M & 11.31 & 11.00 & 10.93 & 11.05 & 18.92 & 16.13 & 28.25 & 21.10 \\
\hline & SEM & 0.72 & 0.80 & 0.37 & 0.84 & 1.52 & 1.73 & 2.05 & 1.74 \\
\hline & C.D & 1.44 & 1.60 & 0.752 & 2.39 & 3.03 & 3.46 & 4.09 & 4.9 \\
\hline & C.V & 7.81 & 8.98 & 4.22 & 13.28 & 9.83 & 13.17 & 8.90 & 14.28 \\
\hline
\end{tabular}


Table.6 Mean performance and stability parameters for Grain Iron content $(\mathrm{mg} / \mathrm{kg})$ and Grain Zinc content (mg/kg) of rice (Oryza sativa L.) Genotypes

\begin{tabular}{|c|c|c|c|c|c|c|c|}
\hline \multirow{2}{*}{ S.no } & \multirow{2}{*}{ Genotypes } & \multicolumn{3}{|c|}{ Grain Iron content(mg/kg) } & \multicolumn{3}{|c|}{ Grain Zinc content(mg/kg) } \\
\hline & & Mean & $\mathbf{B i}$ & $\mathbf{S}^{2} \mathbf{D i}$ & Mean & $\mathbf{B i}$ & $\mathbf{S}^{2} \mathbf{D i}$ \\
\hline 1 & RPHP-7 & 9.31 & 3.52 & -0.14 & 15.76 & 0.87 & 4.32 \\
\hline 2 & RPHP-10 & 9.88 & 0.90 & 0.01 & 17.92 & 1.11 & $21.35 * *$ \\
\hline 3 & RPHP-16 & 10.44 & -7.44 & 0.47 & 17.76 & 1.15 & $7.89 *$ \\
\hline 4 & RPHP-21 & 10.30 & -2.16 & -0.04 & 18.19 & 1.20 & -1.53 \\
\hline 5 & RPHP-37 & 10.55 & -1.20 & $2.42 * *$ & 22.16 & 1.21 & -1.66 \\
\hline 6 & RPHP-45 & 9.11 & 0.80 & -0.02 & 20.96 & 0.61 & -1.51 \\
\hline 7 & RPHP-48 & 13.38 & 4.69 & $37.98 * *$ & 21.49 & 1.23 & $11.36 * *$ \\
\hline 8 & RPHP51 & 10.97 & -4.26 & $15.65 * *$ & 17.58 & 0.81 & -1.11 \\
\hline 9 & RPHP-52 & 9.81 & 1.12 & 0.020 & 18.72 & 0.69 & -1.16 \\
\hline 10 & RPHP-56 & 10.95 & 3.31 & $4.80 * *$ & 20.46 & -0.12 & 0.96 \\
\hline 11 & RPHP59 & 10.17 & 3.07 & -0.19 & 19.97 & 0.89 & $8.58^{*}$ \\
\hline 12 & RPHP 80 & 11.74 & -3.86 & -0.14 & 20.70 & 0.96 & 4.71 \\
\hline 13 & RPHP 81 & 10.26 & 2.60 & $3.03 * *$ & 23.07 & 1.61 & 0.67 \\
\hline 14 & RPHP84 & 9.67 & 3.69 & -0.21 & 25.25 & 1.89 & -1.05 \\
\hline 15 & RPHP87 & 11.18 & -5.46 & 0.64 & 21.14 & 0.74 & -1.53 \\
\hline 16 & RPHP90 & 8.46 & 1.27 & $0.93 *$ & 14.51 & 0.79 & -0.78 \\
\hline 17 & RPHP91 & 11.23 & -1.06 & -0.21 & 28.21 & 1.53 & $18.02 * *$ \\
\hline 18 & RPHP92 & 12.27 & 4.59 & 0.098 & 29.83 & 1.03 & $19.59 * *$ \\
\hline 19 & RPHP 103 & 10.54 & 0.99 & $4.10 * *$ & 23.75 & 1.03 & -1.22 \\
\hline 20 & RPHP 104 & 11.37 & -1.35 & $2.17 * *$ & 20.12 & 0.52 & $10.26^{*}$ \\
\hline 21 & RPHP 105 & 9.94 & -4.02 & -0.20 & 21.48 & 0.59 & 4.12 \\
\hline 22 & RPHP 106 & 12.83 & -2.45 & 0.09 & 20.74 & $0.61^{*}$ & -1.88 \\
\hline 23 & RPHP 107 & 10.79 & 4.55 & $2.20 * *$ & 22.32 & $1.33 *$ & -1.87 \\
\hline 24 & RPHP 108 & 14.83 & 21.00 & $0.96 *$ & 22.66 & 1.00 & 0.39 \\
\hline 25 & RPHP 114 & 14.43 & 4.50 & 0.44 & 21.78 & 0.71 & -0.33 \\
\hline 26 & RPHP 129 & 10.25 & -1.65 & $3.69 * *$ & 19.34 & 0.95 & -1.44 \\
\hline 27 & RPHP 130 & 12.74 & 3.47 & $0.78 *$ & 22.22 & 0.89 & $64.19 * *$ \\
\hline 28 & RPHP 134 & 14.84 & 10.18 & 0.12 & 21.44 & 1.33 & 1.28 \\
\hline 29 & RPHP 135 & 13.09 & -4.64 & 0.14 & 18.24 & 1.15 & 0.44 \\
\hline 30 & RPHP 138 & 9.68 & 3.46 & -0.17 & 22.28 & 1.14 & -1.19 \\
\hline 31 & RPHP 157 & 11.84 & 0.57 & $3.79 * *$ & 24.01 & 1.33 & 0.32 \\
\hline 32 & RPHP 158 & 10.54 & 0.56 & $2.37 * *$ & 23.32 & 0.60 & 2.61 \\
\hline 33 & RPHP 163 & 10.60 & -6.33 & -0.08 & 21.03 & 1.28 & 2.20 \\
\hline 34 & RPHP 165 & 9.76 & 0.72 & $1.37 * *$ & 20.69 & 1.60 & 0.07 \\
\hline 35 & RPHP 166 & 11.31 & 9.10 & 0.19 & 17.47 & $0.833 *$ & -1.88 \\
\hline 36 & 1702 & 10.54 & 0.56 & $2.37 * *$ & 23.32 & 0.60 & 2.61 \\
\hline 37 & 1708 & 10.60 & -6.33 & -0.08 & 21.03 & 1.28 & 2.209 \\
\hline & G.M & 11.05 & & & 21.10 & & \\
\hline & C.D & 2.39 & & & 4.9 & & \\
\hline & C.V & 13.28 & & & 14.28 & & \\
\hline & SEM & 0.84 & & & 1.74 & & \\
\hline
\end{tabular}


The Environment + (Genotype $\mathrm{x}$ Environment) was significant for all the characters, when tested against pooled error and all the characters shown significant differences grain iron content, when tested against pooled deviation. It is indicating distinct nature of environments and genotype $\mathrm{x}$ environment interactions in phenotypic expression.

Significance of Environment (linear) component for grain iron content showed no significant differences, when tested against pooled error and pooled deviation but grain zinc content showed significantly differences. It indicates difference between the environments and their influence on genotypes for expression of these characters. The findings of Panwar et al., (2008) and Das et al., (2010) were in accordance with the present results.

The Genotype $\mathrm{x}$ Environment (linear) interaction was significant for both characters, when tested against pooled error and tested against pooled deviation. This indicated significant differences among the genotypes for linear response to environments (bi) behavior of the genotypes could be predicted over environments more precisely and G X E interaction was outcome of the linear function of environmental components. Hence, prediction of performance of genotypes based on stability parameters would be feasible and reliable.

\section{Grain iron content $(\mathrm{mg} / \mathrm{kg})$}

The Genotypes, environments and both components of Genotype X Environment interaction were found to be significant when tested against pooled error and genotypes showed significant, tested against pooled deviation. Earlier similar kind of results reported by Oikeh et al., (2004), Velu et al., (2012), Suwarto and Nasrullah (2011), Prasanna et al., (2011).
Evaluation of the genotypes for stability parameters for the character grain Iron content revealed that for twenty one genotypes deviation from regression $\left(\mathrm{S}^{2} \mathrm{~d}_{\mathrm{i}}\right)$ was no significant indicating that their performance can be predicted (Table 5).

Among genotypes studied, the genotypes RPHP 106, RPHP 114, RPHP 134 and RPHP 135 were considered stable as they recorded high mean $(\mu)$ with regression coefficient $\left(b_{i}\right)$ near 'unity' and non-significant deviation from regression $\left(\mathrm{S}^{2} \mathrm{~d}_{\mathrm{i}}\right)$.

\section{Grain zinc content $(\mathrm{mg} / \mathrm{kg})$}

The Genotypes, environments and both linear and nonlinear components of Genotype $\mathrm{X}$ Environment interactions showed significance for grain Zinc content, when tested against pooled error and deviation. Earlier similar kind of results reported by Earlier, Oikeh et al., (2004), Velu et al., (2012), Suwarto and Nasrullah (2011) and Prasanna et al., (2011).

Evaluation of the genotypes for stability parameters for the character grain Zinc content revealed that for twenty nine genotypes deviation from regression $\left(\mathrm{S}^{2} \mathrm{~d}_{\mathrm{i}}\right)$ was no significant indicating that their performance can be predicted (Table 6).

Among the genotypes studied, the genotypes RPHP 81, RPHP 84, RPHP 103 and RPHP 157 were considered stable as they recorded high mean $(\mu)$ with unit regression coefficient $\left(b_{i}\right)$ and non-significant deviation from regression $\left(\mathrm{S}^{2} \mathrm{~d}_{\mathrm{i}}\right)$ and considered as stable.

The genotype suitable for better environment with predictable performance was RPHP 107 which recorded greater than 'unit' regression and non-significant deviation from regression.

The genotypes viz., RPHP 166 and RPHP 106 exhibited high mean $(\mu)$ with regression 
coefficient $\left(b_{i}\right)$ less than 'unity' and nonsignificant deviation from regression $\left(\mathrm{S}^{2} \mathrm{~d}_{\mathrm{i}}\right)$ and were identified for resource scarce environments.

In conclusion, the selection of stable and desirable genotypes was made based on the parameters viz., mean $(\mu)$, regression coefficient $\left(b_{i}\right)$ and deviation from regression $\left(\mathrm{S}^{2} \mathrm{~d}_{\mathrm{i}}\right)$ of Eberhart and Russell (1966) model, since this model is widely adopted and relatively simple. The genotypes RPHP 114 and RPHP 134 recorded high grain iron content and were stable, however the grain Zinc content and grain yield of these genotypes was moderate to high. The genotype RPHP 91 and RPHP 92 recorded high grain Zinc content but they were unstable in their performance. Further the grain Iron content of these genotypes was moderate with high grain yield but unpredictable performance.

Based on Eberhart and Russell (1966) model, two genotype RPHP 103 and RPHP 104 recorded high grain yield with moderate grain Iron and zinc content. These genotypes were also stable for other yield contributing characters. The genotype RPHP 106 recorded moderate grain yield, grain iron and zinc content and was stable in its performance.

\section{References}

Becker, H.C., Leon, J. 1988. Stability analysis in plant breeding. Plant Breeding. 101: 123.

Bouis, E. H. 2002. Plant breeding: a new tool for fighting micronutrient malnutrition. Journal of Nutrition 132:491-94.

Bouis, H. E and Welch, R. M., 2010. Biofortification- a sustainable agricultural strategy for reducing micronutrient malnutrition in the global South. Crop Sci. 50, 20-32.

Cichy, K. A., Shana, F., Kenneth, L. G and George, L. H. 2005. Inheritance of seed zinc accumulation in navy bean. Crop Science 45: 864-70.

Das, S., Misra, R.C and Patnaik, M. C. 2009. G $\mathrm{x} E$ interaction of late duration rice genotypes in different models and evaluation of adaptability and yield stability. Indian Journal of Crop Science. 4(1-2): 101-106.

Eberhart, S. A and Russell, W. A. 1966. Stability parameters for comparing varieties. Crop Science.6: 36-40.

FAO. 2010. FAO news release (http://www.wfp.org/hunger/stats).

Fischer, R. A and Yates, F. 1967. Statistical Tables for Biological Agricultural and Medical Research. Olive Boyd, Edinburgh.

Ghandilyan, A., Vreugdenhil, D and Aats, M.G.M. 2006. Progress in the genetic understanding of plant iron and zinc nutrition. Physiologia Plantarum 126: 407-17.

Grafius, A. E. (1959). Heterosis in barley. Agronomy Journal. 51: 551-554.

Gregorio, G. B. 2002. Progress in breeding for trace minerals instaple crops. Journal of Nutrition 132: 500-502.

Hariprasanna, K., Agte. V., Prabhakar and Patil, J. V. 2012. Genotype $\times$ environment interactions for grain micronutrient contents in sorghum [Sorghum bicolor (L.) Moench]. Indian J. Genet., 72(4): 429-434.

Lodha, M. L. Prasanna, B. M and Pal, R. K. 2005. Alleviating 'hidden hunger' through better harvest. Ind Farming. 54(12): 2023.

Lynch, S. R. 2003. Iron physiology. Benjamin Caballero, (Ed.) Encyclopedia of Food Sciences and Nutrition. 2nd edn. Oxford, England: Elsevier Science Ltd.

Ministry of Agriculture, Govt. of India. (14105) and (ON321) (2O11-12)

Mosavi, A. A., Jeodar, N. B and Kazemitabar, K. 2013. Environmental responses and Stability analysis grain yield of some rice genotypes. World Applied Sciences Journal. 21 (1): 105-108.

Oikeh, S. O., Menkir, A., Dixon, B. M., Welch, R. M., Glahn, R. P and Gauch, G. 2004. Environmental stability of iron and zinc 
concentrations in grain of elite early maturing tropical maize genotypes grown under field conditions. Journal of Agricultural Science 142: 543-51.

Panwar, L.L., Joshi, V.N and Ali, M. 2008. Genotype X Environment interaction in scented rice. Oryza. 45(1): 103-109...

Pfeiffer, W. H and McClafferty, B. (2007) Harvest Plus: breeding crops for better nutrition. Crop Sci. 47: 88-105.

Prasanna, B. M., Mazumdar, S., Chakraborti, M., Hossain, F., Manjaiah, K. M., Agrawal, P. K., Guleria, S.K and Gupta, H. S. 2011. Genetic variability and Genotype $\times$ Environment interactions for kernel Iron and Zinc concentrations in maize (Zea mays) genotypes. Indian Journal of Agricultural Sciences 81 (8): 704-11.

Rasyad, A., Gulat, M. E and Van Sanford, D. A. 2012. Genotype $\mathrm{X}$ Environment interaction and stability of yield components among rice genotypes in riau province, Indonesia. SABRAO Journal of Breeding and Genetics. 44(1):102-111.

Sahrawat, K. L., Ravi Kumar, G and Rao, J. K. 2002. Evaluation of triacid and dry ashing procedures for determining potassium, calcium, magnesium, iron, zinc, manganese and copper in plant materials. Communications in Soil Science and Plant Analysis 33:95-102.

Solomons, N. W. 2003. Zinc deficiency. (In) Encyclopedia of Food Sciences, 2nd edn. Benjamin Ceballero (Ed.) Oxford England: Elsevier Science Ltd.

Somana, P., Wattana, P., Suriharn, B and Sanitchon, J. 2013. Stability and genotype by environment interactions for grain Anthocyanin content of the Thai Black Glutinous Upland Rice (Oryza sativa L.).
Sabrao Journal of Breeding and Genetics. 45(3): 523-532.

Suwarto and Nasrullah. 2011. Genotype $\times$ Environment interaction for Iron concentration of rice in Central Java of Indonesia. Rice Sci., 18 (1): 75 - 78.

Swamy, M. N and Kumar, B. M. D. 2003. Stability analysis for grain yield and its components in rice. Karnataka Journal of Agricultural Sciences. 16 (2): 223 - 227.

Tariku, S., Lakew, T., Bitew, M and Asfaw, M. 2013. Genotype by environment interaction and grain yield stability analysis of rice (Oryza sativa L.) genotypes evaluated in north western Ethiopia. Net Journal of Agricultural Science. 1(1):10-16.

Underwood, B. A. 2000. Overcoming micronutrient deficiencies in developing countries: Is there a role for agriculture? Food and Nutrition Bulletin 21: 356-60.

Velu, G., Singh, R. P., Huerta-Espino, J., Pena, R.J., Arun, B., Mahendru Singh, A., Yaqub Mujahide, M., Sohuf, V. S., Mavif, G. S., Crossaa, J., Alvarado, G., Joshi, A. K and Pfeiffer,W. H. 2012. Performance of biofortified spring wheat genotypes in target environments for grain zinc and iron concentrations. Field Crops Research 137: 261-267.

Welch, R. M and Graham, R. D., 2004. Breeding for micronutrients in staple food crops from a human nutrition perspective. J. Exp. Bot. 55.353 - 364.

Ye, X., Al-Babili, S., Kloti A., Zhang, J., Lucca, P., Beyer, P and Potrykus, I. 2000. Engineering the pro vitamin A (b-carotene) biosynthetic pathway into (carotenoid-free) rice endosperm. Science 287:303-5.

\section{How to cite this article:}

Sriram Ajmera, S. Sudheer Kumar and Ravindrababu, V. 2017. Genotype $\times$ Environment Interactions and Stability Analysis for Grain Iron and Zinc Concentrations in Rice (Oryza Sativa L.) Genotypes. Int.J.Curr.Microbiol.App.Sci. 6(7): 1902-1913. doi: https://doi.org/10.20546/ijcmas.2017.607.227 